\title{
我々の経験した手指外傷について
}

田川市立病院整形外科

$\begin{array}{lll}\text { 村 田 敬 } & \text { 典 } \\ \text { 藤 } & \text { 井 } & \text { 徹 }\end{array}$

\section{Observation of Hand and Finger Injury in Our Clinic}

By

\section{Y. Murata \& T. Fujii}

Orthopedic Department, Tagawa City Hospital

\section{まえがき}

手指の外傷に関しては, すでに多くの専門家によつ て詳細汇報告されているが，我々屯当外来を訪れた手 指外傷患者の臨床的観察を行つたので, 若干の考察を 加えて報告する.

昭和38年11月より 40 年 8 月迄の 1 年10个月間に, 我 々の外来を訪れた患者総数注 3731 名で, そのうち, 手 指外傷患者数は 92 名でその比率は全体の $2.4 \%$ 亿当る.

これを他部外傷との割合からみるとかなりの高率にな ると思われる.

性別では男 68例（74\%)，女 24 例 (26\%) で男に多 い.

年令的には20才から 30 才代が全体の60\%をしめる.

左右別では右が62例 $(67 \%)$ 左が30例 (33\%) であ つた.

原因別にみると労働災害が約 $40 \%$ ，交通事故が約 20 \%, スポーツ外傷が約15\%, その他が約 $25 \%$ となつて いる.（表1)

種類別では挫創傷 $43.8 \%$, 骨折 $28.3 \%$, 切断 $16.3 \%$ 捻挫, 脱臼11.9\%となる.（表 2 )

各手指別にみる之骨折例では I 指よりV指迄たいし た変動がなく, 指節別では末節骨40\%基節骨40\%, 上多

表 1 原因

\begin{tabular}{|c|c|c|c|}
\hline 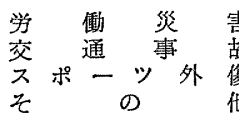 & 害 & $\begin{array}{l}37 \text { 例 } \\
18 \\
14 \\
23\end{array}$ & $\left.\begin{array}{l}(40.2 \%) \\
(19.6 \\
(15.2 \\
(25.0\end{array}\right)$ \\
\hline 計 & & 92 & $(100.0)$ \\
\hline
\end{tabular}

表 2 種 類

\begin{tabular}{|c|c|c|c|c|c|}
\hline $\begin{array}{l}\text { 挫 } \\
\text { 骨 } \\
\text { 招 } \\
\text { 捻 }\end{array}$ & 挫 & - 脱 & $\begin{array}{l}\text { 傷 } \\
\text { 折 } \\
\text { 断 } \\
\text { 白 }\end{array}$ & $\begin{array}{l}40 \text { 例 } \\
26 \\
15 \\
11\end{array}$ & $\left.\begin{array}{l}(43.5 \%) \\
(28.3 \\
16.3 \\
11.9\end{array}\right)$ \\
\hline \multicolumn{4}{|c|}{ 計 } & 92 & $(100.0)$ \\
\hline
\end{tabular}

表 3 外稘手指別分類

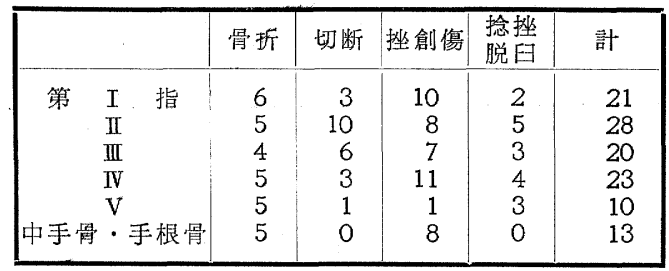

表 4 骨 折 指 節 別

\begin{tabular}{|lll|cc|}
\hline 末 & 穊 & 骨 & 12 例 & $(40 \%)$ \\
中 & 䬣 & 骨 & 1 & $(3.3)$ \\
基 & 節 & 骨 & 12 & $(40$ \\
中 & 手 & 骨 & 3 & $(10)$ \\
手 & 根 & 骨 & 2 & $(6.7)$ \\
\hline & 計 & & 30 & $(100.0)$ \\
\hline
\end{tabular}

表5 切断 指 節 別

\begin{tabular}{|ccc|cc|}
\hline 末 & 節 & 骨 & 3 例 & $(13 \% \%)$ \\
中 & 節 & 骨 & 19 & $(82.6)$ \\
基 & 節 & 骨 & 1 & $(4.4)$ \\
\hline & 計 & & 23 & $(100.0)$ \\
\hline
\end{tabular}

く，中節骨に少ないのが目立つている．

切断例では II 指，指任多く諸家の報告之一致する. 指節別では骨折例之対称的に $82.6 \%$ 之中節骨に圧倒的 
に多い。（表 $3 ）($ 表 4 )（表 5 ).

\section{治療並びに予後}

骨折では骨折転位の少ないものに対してアルフェン ス固定18例，転位のみられたすのに対して徒手整復後 X線透視下にてキルシュナ一鋼線固定 5 例, 舟状骨々 折 2 例之他の 1 例にはギブ ス固定定行つた。

固定期間は2 4週が26例中 22 例で約 $85 \%$ をしめ, こ れを 3 週間以内に限ると 17 例で， $65.4 \%$ であつた，固 定除去後は直ちに温浴練習を行つた。固定期間 4 週以 上に及んだ他の 4 例は, 開放性骨折 1 例, 転位があり 早期の整復不十分であつた 1 例, 舟状骨々折 2 例とで あつた.

これらの予後は運動制限や長期間痛みを訴えたむの が $48 \%$ 之約半数に認め，特に基節骨骨折に於てその予 後が悪く $58.2 \%$ となつている.（表 6 )

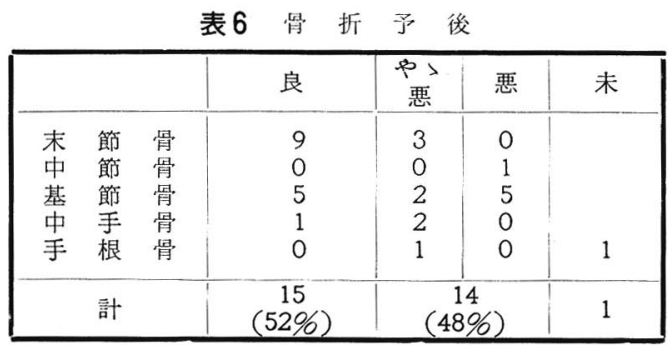

切断例飞於ては, 大部分に通常の断端形成術を行つ たが, 軟部組織が挫滅され，指骨が露出し切断適応か と屯思われた 3 例飞対し, Thenar-palp-flap 法 2 例 Abdominal-flap法 1 例を行つた.

挫創傷例では十分なDébridement之慎重な軟部組織 の取り扱い, 必要に応じての固定, 又捻挫, 脱臼例で は1〜3週の固定で全例良好な結果であつた。

\section{考按}

以上我々の経験した于指外眇例を述べたが，狄原ら も指摘しているように, 手指外傷例は病院の立地条件 にて異るこよは当然と考えられるので，症例数及び局 在をあげるにとどめた。

手指外傷治療の終局はピンチ等の巧緻性及び把握之 いう独特な機能の回復にあると思われるが, 我々の経 験した手指骨々折の予後に 於ては，末節骨々折の場 合, 関節内骨折や開放性骨折を除けば比較的良好であ つた.

基節骨々折に於ては半数以上に予後が悪く, 荻原ら
に依れば $2 / 3$ に障害をみたという。

これらはNo-man's land内の骨折にて，指屈筋腱癒 着が機能と最も大きな問題となつているむのと思われ 今後の重要な課題であろう.

我々は手指骨々折 26 例中 5 例任対しキルシュナ一鋼 線固定を行い，うち 3 例に予後不良をみたが，特任悪 かつた 1 例は基節骨粉厒骨折に対し行つたすので, 指 屈筋腱瘾着を抢こして著しい運動制限を残した。（図 1) (図 2 ) (図3)

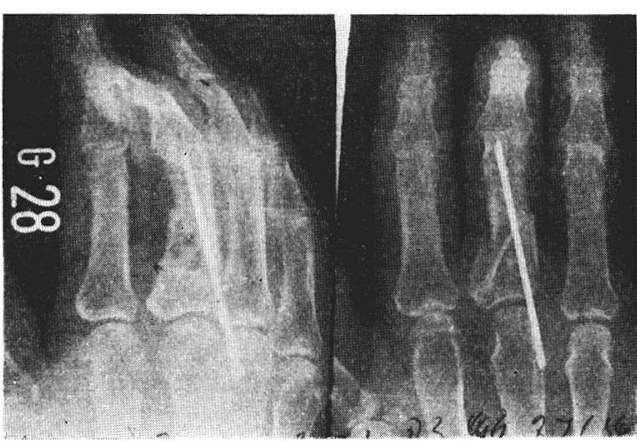

図 1

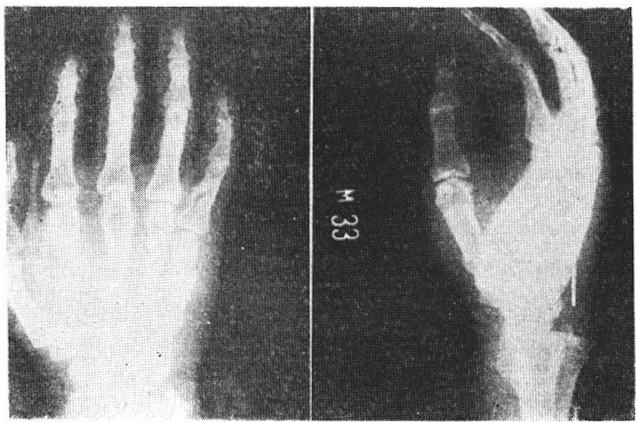

図 $\quad 2$
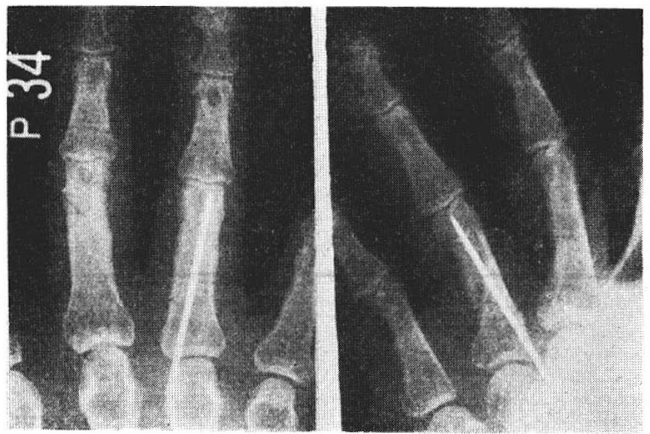

図 3 
一般に手指骨々折の治療は諸富, 田島, 難波らに依 れば, 手指骨新鮮骨折では観血的手術を要するものは ほとんどなく, 非観血的整復で十分であるとし,大方の 意見むその様であり, 我々あ少数例であつたが同様に 感じた. しかし徒手整復が得られない場合の観血的療 法は, 比較的機能障害を残すことむ多いが, 津下飞依 ればキルシュナー鋼線の䯣内固定よりも，2本を互に cross して固定する方が確実で早期運動む可能である といい, 村上は，ねじつき指骨針於ける経験で良い 結果をみ, 又関節を穿通して固定する場合は，4 週間 以内での除去汇於ては，ほとんど無害であるとしてい るので, 転位が残す機能障害と, 手術による機能障害 との兼㸚合いを考元, どうしても必要な症例には, 早 期に且つ atraumatic に行なえば良好な結果を得るも のと思われる。

次に指切断に際しては, 出来る限り長く残すと共に 断端の性状, 関節の可動性に注意を払い, 早期に治瘜 せしめることが必要であるのは当然であるが, 我々の 経験した Thenar-palp-flap 法の 2 例は, 機能的にも良 好であつたが, Abdominal-flap法の 1 例に於ては, 指 切断をまぬがれ，指短縮こそみずにすんだが，不幸に む化膿し，長期固定も合まつて，指関節の運動制限が 残り, 又Finger-tipの知覚異常を訴える結果となつた。

この様に切断例に於ては例え形態的に良好な長断端 を残したとしても，田島がいうように，手の綜合的機
能の観点から，指末節が正常の長さを保つこよよりも， 正常な知覚を保つととの方が遙かに重要であるという ことになれば，現在に於ても尚 100\%の治癒をみられ ない手指外傷治療に尚一層のむつかしさを感じさせら れた.

\section{むす び}

1. 我々は当外来を訪れた手指外傷の統計的観察を 行い, 手指骨々折之切断の治療, 予後について考察し た.

2. 手指骨新鮮骨折に対しては, 非観血的療法を, 又固定期間は原則として，3 週間とした。

3. 指切断例に於ては，社会復帰が遅れるが，経済

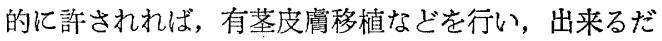
け長断端を残すとととした。

\section{参 考 文 献}

1) 諸富：整形外科. $16(10): 827,1965$.

2) 津下：整形外科. $16(10): 874,1965$.

3）津下：整形外科. $9(2): 135,1958$.

4) 田島：整形外科. 14(8): 704, 1963.

5) 荻原：整形外科. 15(10): 872, 1964 .

6) 難波：整形外科. 14(8):694, 1963.

7) 田島：災医. 5(1): 1, 1962.

8) 村上: 災医. 4(5)：9，1962.

9) 高橋: 整形外科. 16(3):233, 1965.

10) 木住野：整形外科. 14(8): 702, 1963. 